\title{
Biosynthesis of Copper Oxide Nanoparticles by Marine Streptomyces MHM38 and their Preventive Efficacy Against Paracetamol-Inducing Hepatic Damage of Albino Rats
}

\section{Moaz Hamed ( $\nabla$ Moaz-micro@hotmail.com )}

National Institute of Oceanography and Fisheries Mediterranean Sea Branch https://orcid.org/00000002-2608-085X

\section{Hanaa S.S. Gazwi}

Department of Agricultural Chemistry, Faculty of Agriculture, Minia University, El-Minia, Egypt

\section{Asmaa M. Youssif}

Department of Botany and Microbiology, Faculty of Science, Alexandria University

\section{Sara I. Bukhari}

1Department of Pharmaceutics, College of Pharmacy, King Saud University, Riyadh, Saudi Arabia https://orcid.org/0000-0002-6002-9249

\section{Mohamed H. Al-Agamy}

Department of Pharmaceutics, College of Pharmacy, King Saud University, Riyadh, Saudi Arabia https://orcid.org/0000-0001-9868-0355

\section{Hesham H. Radwan}

1Department of Pharmaceutics, College of Pharmacy, King Saud University, Riyadh, Saudi Arabia https://orcid.org/0000-0002-2509-327X

\section{Research}

Keywords: marine Streptomyces sp. MHM38, copper oxide nanoparticles, UV-vis spectroscopy, XRD, EDX, TEM, Antimicrobial activity, oxidative stress

Posted Date: February 15th, 2021

DOl: https://doi.org/10.21203/rs.3.rs-37392/v3

License: (a) (1) This work is licensed under a Creative Commons Attribution 4.0 International License. Read Full License 
Version of Record: A version of this preprint was published on January 4th, 2021. See the published version at https://doi.org/10.1155/2021/6693302. 
The authors have withdrawn this preprint from Research Square 